\title{
Manajemen Radio Suara Muslim Surabaya
}

\section{(Manajemen Media Islam atau Islami)}

\author{
Annisa Shah Rizky \\ Pascasarjana Universitas Islam Negeri Sunan Ampel Surabaya \\ annisashab@gmail.com
}

\begin{abstract}
Indonesia with Muslim majority population is the right target when building an Islamic media industry or building a media industry in a religious perspective, one of the Islamic radio stations in Indonesia is Radio Suara Muslim located in Surabaya but with its name that has an Islamic logo, is it a radio station with a context Islam is always in the management of Islam or the context of Islam in the establishment of a radio station is only for symbols. The purpose of this study to determine the management of Radio Suara Muslim Surabaya is an Islamic or Islami media management. The research method used in this research is descriptive qualitative and sampling using purposive sampling technique because not all samples have criteria that are in accordance with the phenomenon under study. The results of the research show that the management of Radio Suara Muslim Surabaya is almost close to Islamic with Islami of management which relying on three requirements of Islamic media according to Satrio Arismunandar among others 1) Islamic media must be owned by Muslims, 2) Islamic media more or less must carry the mission of dakwah and spread the values of Islamic teachings, 3) Islamic media must apply the rules, ethics values of Islamic teachings in the business of media companies and editorial activities and Radio Suara Muslim Surabaya impose a standard policy of at least 7 practices islamic in day
\end{abstract}

Keywords: Media Industry Management, Radio Suara Muslim Surabaya, Islamic or Islami Media

Management

\begin{abstract}
Abstrak
Indonesia dengan penduduknya yang mayoritas muslim merupakan sasaran yang tepat ketika membangun sebuah industri media Islam atau membangun industri media dalam sudut pandang religius, salah satu radio Islam di Indonesia ialah Radio Suara Muslim yang terletak di Surabaya namun dengan namanya yang berlogokan Islam apakah stasiun radio dengan konteks islam selalu dalam manajemen Islam ataukah konteks Islam dalam berdirinya sebuah stasiun radio hanyalah menjadi sebuah konsumsi simbol. Tujuan penelitian ini untuk mengetahui manajemen dalam Radio Suara Muslim Surabaya merupakan manajemen media Islam atau Islami. Metode penelitian yang digunakan dalam penelitian ini adalah deskriptif kualitatif dan pengambilan sampel dengan menggunakan teknik purposive sampling karena tidak semua sampel memiliki kriteria yang sesuai dengan fenomena yang diteliti. Didapatkan hasil penelitian bahwa manajemen Radio Suara Muslim Surabaya hampir mendekati dengan manajemen Islam yang Islami dengan disandarkan pada tiga syarat media Islam menurut Satrio Arismunandar dintaranya 1) Media Islam harus dimiliki oleh orang Islam, 2) Media Islam sedikit banyak harus mengemban misi dakwah
\end{abstract}

Jurnal Kopis: Kajian Penelitian dan Pemikiran Komunikasi Penyiaran Islam Volume 2 issue 2 bulan Februari tahun 2020 
dan menyebarkan nilai-nilai ajaran Islam, 3) Media Islam harus menerapkan aturan, etika, dan nilai-nilai ajaran Islam dalam menjalankan bisnis perusahaan media dan aktivitas keredaksian (editorial) dan Radio Suara Muslim Surabaya memberlakukan kebijakan standart minimal 7 amalan harian.

Kata Kunci: Manajemen Industri Media, Radio Suara Muslim Surabaya, Manajemen Media Islam

atau Islami

\section{Pendahuluan}

Industri media di Indonesia telah berkembang sejak akhir 1980-an ketika beberapa pihak yang tidak berprofesi menjadi wartawan memiliki media pers, misalnya partai golkar yang mendirikan Suara Karya, Harmoko (menteri penerangan saat itu) membeli Pos Kota, dan BJ Habibie (menteri riset dan teknologi pada saat itu) membeli republika. Pada masa itu pemerintah Indonesia dibawah kepemimpinan presiden Soeharto, dan pada saat itu peraturan-peraturan yang ada masih sangat mengekang sehingga pers pun kesulitan untuk mengkritik pemerintah. Beberapa surat kabar dibredel, penyiaran televisi dan radio pun ketat diawasi, bahkan ada yang lebih dari itu. ${ }^{1}$

Pada tahun 1998 bersamaan dengan jatuhnya presiden Soeharto, muncullah era yang dinamakan era reformasi. Pada era ini media mulai berkembang sesuai dengan peraturan-peraturan tentang hak siar media sampai saat ini dan industri media yang dulunya terkekang oleh peraturan mulai bermunculan dengan bebas. ${ }^{2}$

Salah satu industri media di Indonesia yang pada saat itu juga mulai mengepakkan sayapnya untuk berevolusi ialah radio, dan pada tahun 1980-an ini radio mencapai masa emasnya karena tingkat pertumbuhannya yang sangat tinggi. ${ }^{3}$ Di Indonesia sendiri telah berdiri berbagai macam stasiun radio baik dimiliki swasta maupun negeri, radio komersil maupun komunitas.

Radio memiliki beberapa segmentasi atau jenis yang pembagiannya juga dilakukan dengan berbagai perspektif. Selain hadir dalam bentuk kategori secara teknis, penyajian, tingkat konsumsi, dan lain sebagainya, segmen radio di Indonesia juga hadir dalam sudut pandang "religius" dan salah satunya ialah segmen radio Islam. Untuk negara dengan mayoritas penduduknya adalah muslim, merupakan sasaran yang tepat bagi industri media untuk mendirikan sebuah stasiun radio islam. Suara Muslim Surabaya yang berada dalam naungan Suara Muslim Radio Network merupakan stasiun radio yang masih aktif beroperasi di Surabaya. Namun yang akan dibahas dalam jurnal ini adalah apakah stasiun radio dengan konteks islam selalu dalam manajemen islam ataukah konteks islam dalam berdirinya sebuah stasiun radio hanyalah menjadi sebuah konsumsi simbol.

Dalam bahasa Arab manajemen disebut dengan idarah. Kata idarah diambil dari kata adartasy-syai'a dalam Elias' Modern Dictionary English Arabic kata management (inggris) sepadan dengan kata tadbir, idarah, siyasah dan qiyadah dalam bahasa Arab.

${ }^{1}$ Yanuar Nugroho, Shita Laksmi. Jurnal Lanskap Industri Media di Indonesia, Hal. 5

${ }^{2} \mathrm{ibid}$

${ }^{3}$ Agus Sudibyo, Ekonomi Politik Media Penyiaran, (Yogyakarta, LkiS, 2004) Hal. 187

Jurnal Kopis: Kajian Penelitian dan Pemikiran Komunikasi Penyiaran Islam

Volume 2 issue 2 Februari tahun 2020 
Tadbir merupakan bentuk masdar dari kata kerja dabbara, yudabbiru, tadbiran. Jadi tadbir berarti penertiban, pengaturan, pengurusan, perencanaan dan persiapan. ${ }^{4}$

Secara definitif manajemen dalam pandangan Islam tidak disebutkan khusus dalam Al-Qur'an tentang pengertian manajemen itu sendiri, namun AlBuraey menyatakan bahwa walaupun tiada perkataan khusus tentang manajemen dalam Al-Qur'an, namun penggunaan perkataan yudabbiru dalam bahasa Arab dapat diartikan mengarah, mengendalikan, mengurus, melaksanakan, mengatur, dan mengawal. ${ }^{5}$

Dalam Q.S Al-Ra'd ayat 2, Allah berfirman :

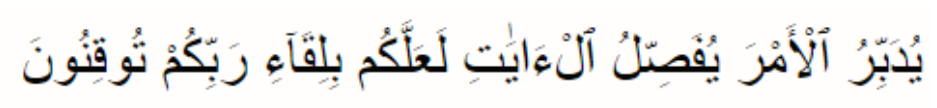

Artinya : Allah mengatur urusan (makbluk-Nya), menjelaskan tanda-tanda (kebesaran Nya), supaya kamu meyakini pertemuan(mu) dengan Tubanmu.

Dengan demikian dapat dinyatakan bahwa manajemen dalam pandangan Islam sebenarnya telah ada sejak sejarah peradaban manusia dan konsep manajemen dalam Islam telah lahir sejak kelahiran Islam yakni zaman Rasulullah saw.

Diantara karakteristik yang membedakan teori manajemen dalam islam dengan teori lain adalah fokus dan konsen teori islam terhadap segala variabel yang berpengaruh terhadap aktivitas manajemen dalam dan luar organisasi, dan hubungan perilaku individu terhadap faktor-faktor sosial yang berpengaruh. Teori Islam memberikan injeksi moral dalam manajemen, yakni mengatur bagaimana seharusnya individu berperilaku. Tidak ada manajemen dalam Islam kecuali ada nilai atau etika yang melingkupinya, sebagaimana tidak mungkin membangun masyarakat muslim tanpa didasari dengan akhlak. Berdasarkan penjelasan tersebut, teori manajemen Islam bersifat universal dan komprehensif, dan memiliki karakteristik sebagai berikut :

1. Manajemen dan mayarakat memiliki hubungan yang sangat erat, manajemen merupakan bagian dari sistem sosial yang dipenuhi dengan nilai, etika, akhlak, dan keyakinan yang bersumber dari Islam.

2. Teori manajemen islam menyelesaikan persoalan kekuasaan dalam manajemen, tidak ada perbedaan antara pemimpin dan karyawan. Perbedaan level kepemimpinan hanya menunjukan wewenang dan tanggung jawab. Atasan dan bawahan saling bersekutu tanpa ada pertentangan dan perbedaan kepentingan. Tujuan dan harapan mereka adalah sejenis dan akan diwujudkan bersama.

3. Pegawai dan karyawan menjalankan pekerjaan mereka dengan keikhlasan dan semangat profesionalisme, mereka ikut berkontribusi dalam menetapkan keputusan, dan taatkepada atasan sepanjang mereka berpihak pada nilai-nilai syari'ah.

\footnotetext{
${ }^{4}$ Muhammad, Manajemen Dana Bank Syariah (Yogyakarta: Ekonisia, 2005) Hal.13

${ }^{5}$ Al-Buraey, A.Muhammad, Islam LandasanAlternatif Administratif Pembangunan (Jakarta, CV Rajawali, 1986) Hal. 25

${ }^{6}$ Abu Sinn Ahmad Ibrahim, Manajemen Syariah Sebuah Kajian Histories Dan Kontemporer (Jakarta, PT Raja Grafindo Persada, 2008) Hal. 249

Jurnal Kopis: Kajian Penelitian dan Pemikiran Komunikasi Penyiaran Islam

Volume 2 issue 2 Februari tahun 2020
} 
4. Kepemimpinan dalam Islam dibangun dengan nilainilai syura (musyawarah) dan saling menasehati, dan para atasan bisa menerima kritik dan saran demi kemaslahatan masyarakat publik.

\section{Metode Penelitian}

Metode penelitian yang digunakan adalah deskriptif kualitatif yang bertujuan untuk memaparkan suatu peristiwa atau fakta yang terjadi di Radio Suara Muslim Surabaya misalnya perilaku, persepsi, tindakan dan lain-lain yang dijelaskan dalam bahasa dan katakata secara khusus dengan memanfaatkan metode ilmiah yang $\mathrm{ada}^{7}$

Peneliti mencari data melalui informan sebagai sumber data dan informasi dengan menggunakan teknik purposive sampling, alasan menggunakan teknik purposive sampling adalah karena tidak semua sampel memiliki kriteria yang sesuai dengan fenomena yang diteliti. Oleh karena itu, penulis memilih teknik purposive sampling yang menetapkan pertimbanganpertimbangan atau kriteria-kriteria tertentu yang harus dipenuhi oleh sampel-sampel yang digunakan dalam penelitian ini. ${ }^{8}$

\section{Hasil dan Pembahasan}

\section{Mengenal Radio Suara Muslim Surabaya}

\subsection{Sejarah Radio Suara Muslim Surabaya}

Radio Suara Muslim Surabaya atau Sham FM didirikan pada tanggal 1 Ramadhan 1431 Hijriyah/11 Agustus 2010 tepatnya 7 tahun yang lalu, semangat pendirian Radio 93,8 Sham FM Suara Muslim Surabaya yang saat ini menjadi Suara Muslim Radio Network merupakan bentuk tanggung jawab dan komitmen sosial para pendirinya untuk mendidik sekaligus menyebarkan nilai-nilai kebaikan dengan cita-cita yang mulia yaitu terbentuknya masyarakat yang bermoral, berakhlak, dan berbudaya luhur. Selain itu juga bertujuan menanamkan moral yang baik serta mencerdaskan bangsa agar makin produktif dengan cara yang sesuai aturan serta norma sosial yang berlaku. Komitmen Radio 93,8 Sham FM Suara Muslim Surabaya adalah memberikan pencerahan dengan siaran yang sehat, mendidik, dan bertanggung jawab. Sebagai pemain baru dalam dunia broadcasting khususnya di Surabaya dan umumnya Jawa Timur, Radio 93,8 Sham FM Suara Muslim Surabaya memberikan warna dan format baru bagi khalayak pendengar dengan tidak meninggalkan kodrat radio yang berfungsi untuk menyampaikan pesan atau berita, mendidik serta menghibur.

Radio Suara muslim Surabaya ini memiliki prinsip "dengan satu mic sekali berujar, seribu telinga mendengar" jadi berdakwah melalui radio lebih efektif dari pada berdakwah di masjid atau mimbar, sebab berdakwah dengan menggunakan media radio lebih banyak yang mendengarkan dari pada bertaklim di masjid yang hanya beberapa orang saja yang mendengarkanya. Jika berdakwah menggunakan media radio maka akan ada ratusan ribu jiwa dan hati yang akan terisi dengan

\footnotetext{
${ }^{7}$ Ulber Silalahi, Metode Penelitian Sosial (Bandung, PT Refika Aditama, 2012) Hal. 272

${ }^{8}$ Sugiyono, Metode Penelitian Kualitatif, Kuantitatif dan R\&D (Bandung, PT. Alfabet, 2016) Hal 85

Jurnal Kopis: Kajian Penelitian dan Pemikiran Komunikasi Penyiaran Islam

Volume 2 issue 2 Februari tahun 2020
} 
kekayaan ilmu pengetahuan islam. Sedangkan jika berdakwah di masjid atau di mimbar hanya beberapa orang saja yang mendengarkan.

\subsection{Profil Radio Suara Muslim Surabaya}

Nama Stasiun Radio

: Suara Muslim Surabaya

Frekuensi : 93,8 FM

Slogan Radio

: Mencerahkan, Menyejukkan, Menyatukan

Format Siaran Kata

: Dakwah \& Talk

Format Musik

: Nasyid \& Pop Religius Islami

Radius Jangkauan

: Gerbang Kertosusilapas

Alamat

: Jalan Dinoyo No. 57, Surabaya 60265

Suara Muslim Radio Network :

1) Suara Muslim Surabaya 93,8 FM

2) Suara Muslim Lumajang 89,9 FM

3) Suara Muslim Madiun 88,5 FM

4) Suara Muslim Tuban 88,7 FM

Twitter

:@suaramuslim

Facebook

: Suara Muslim Surabaya

Contact

: 0315625666, 08553000938

Sasaran pendengar : Seluruh Keluarga Muslim

\subsection{Struktur Organisasi Radio Suara Muslim Surabaya}

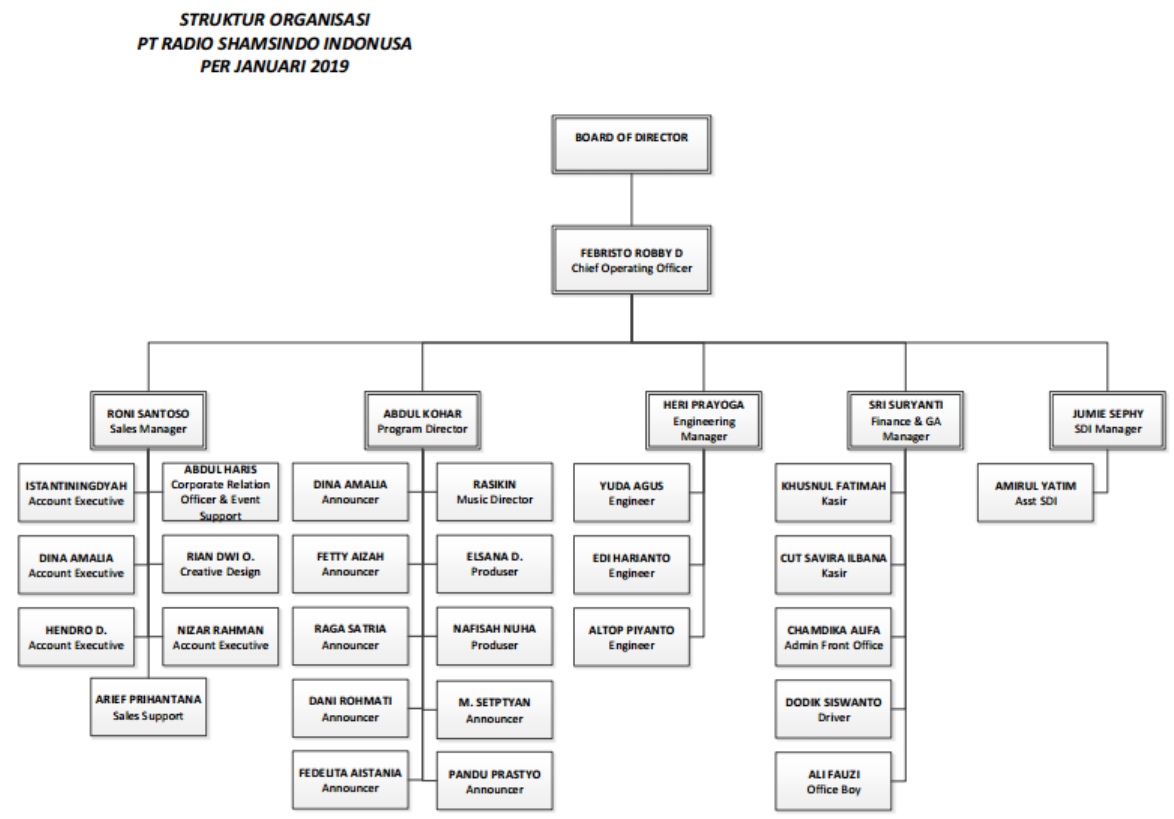

1.4 Visi Radio Suara Muslim Surabaya 
Radio Suara Muslim Surabaya memiliki beberapa visi dan misi, dimana visi dan misi ini akan menjadi target utama didirikannya Radio Suara Muslim Surabaya. Adapun visi Radio Suara Muslim Surabaya adalah menjadi jaringan radio (networked radio station) islam nomer satu di Indonesia.

\subsection{Segmentasi Pendengar Radio Suara Muslim Surabaya}

Segmentasi pendengar radio suara muslim surabaya dengan keseluruhan 446 pendengar dengan perbandingan pendengar kaum ikhwan $49 \%$ dan dari akhwat 51\% pendengar.

\section{Fungsi Manajemen dalam Islam}

Ada beberapa pendapat Barat tentang fungsi-fungsi manajemen, diantaranya :

a. Menurut Newman:

1. Planning

2. Organizing

3. Assembling resources

4. Directing

5. Controlling

b. Menurut Louis A. Alen :

1. Memimpin

2. Merencanakan

3. Menyusun

4. Mengawasi

c. Menurut George R. Terry

1. Planning

2. Organizing

3. Actuating

4. Controlling

Dari beberapa pendapat tersebut, penulis memilih mengambil pendapat dari George R. Terry yang akan dikaitkan dalam fungsi manajemen secara islam dimana fungsi-fungsi manajemen tersebut terdiri dari Planning (perencanaan), Organizing (Pengorganisasian), Actuating (Penggerakan), Controlling (Pengawasan).

\subsection{Planning (perencanaan)}

Perencanaan adalah menetapkan suatu cara untuk bertindak sebelum tindakan itu dilaksanakan. ${ }^{10}$ Dalam perencanaan harus diusahakan untuk menjawab enam pertanyaan sebagai berikut (apa yang barus dikerjakan, mengapa ia harus dikerjakan, bagaimana ia harus dikerjakan, siapa yang harus mengerjakan, dimana ia harus dikerjakan, dan kapan ia harus dikerjakan).

Nabi Muhammad SAW pun bersabda :

\footnotetext{
${ }^{9}$ Djati Julitriarsa dan John Suprihanto, Manajemen Umum Sebuah Penga

${ }^{10}$ Ibid., Hal. 29

إن الله يحب إذ عمل أحدكم العمل أن يتقنه

Jurnal Kopis: Kajian Penelitian dan Pemikiran Kunnunkası renyıaı dı ısım

Volume 2 issue 2 Februari tahun 2020
} 
Artinya: Sesunggubnya Allah sangat mencintai orang jika melakukan sesuatu pekerjaan, dilakukan secara itqan (tepat, terarah, jelas, dan tuntas). (HR. Thabrani).

Dalam Al-Qur'an Allah berfirman,

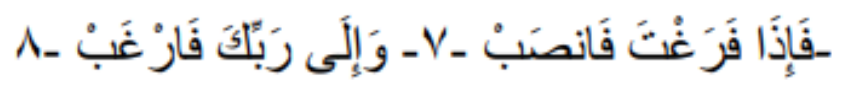

Artinya: Maka apabila kamu telah selesai (dari suatu urusan) kerjakanlah dengan sunggubsunggub (urusan) yang lain. Dan banya kepada Tubanlah bendaknya kamu berbarap. (Q.S Al Insyirah ayat 7-8)

Sehingga dari hadist dan ayat tersebut agama telah mengajarkan sebuah tanggung jawab tentang perencanaan, dimana perencanaan yang baik ialah yang matang dan itqan karena setiap pekerjaan yang dikerjakan dengan baik akan menghasilkan yang baik juga. Sehingga halhal yang baik, bertanggung jawab akan disenangi oleh Allah SWT.

\subsection{Organizing (pengorganisasian)}

Pengorganisasian merupakan kegiatan dasar dari manajemen yang dilaksanakan untuk mengatur seluruh sumber-sumber yang dibutuhkan termasuk manusia, sehingga pekerjaan dapat dilakukan dengan sukses. Dalam hal ini manusia merupakan unsur yang terpenting. Tujuan dari pengorganisasian adalah untuk membimbing manusia-manusia bekerjasama secara efektif. ${ }^{11}$

Allah berfirman dalam surah Al-Imran :

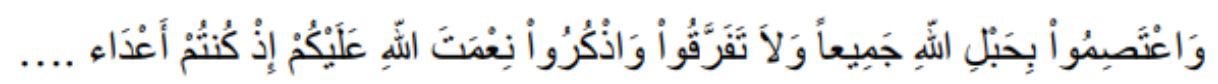

Artinya: Dan berpeganglah kamu semuanya pada tali (agama) Allah, dan janganlah kamu bercerai-berai, dan ingatlah akan nikmat Allah kepadamu ketika kamu dabulu (masa jabiliyah) bermusub-musuban... (Q.S Al-Imran ayat 103$)$

Pengorganisasian merupakan sebuah wadah tentang elemen penting yakni manusia yang memiliki fungsi utama dalam sebuah organisasi baik secara vertikal maupun horizontal.

Ayat diatas juga menunjukkan bahwa ketika sebuah organisasi atau sekumpulan orang itu mampu diorganisir dengan baik maka akan terjalin sebuah kerjasama yang efektif untuk mencapai sebuah cita-cita organisasi, berkomitmen dan bersatupadu dalam melakukan pekerjaan. Maka dari itu sebaliknya apabila manusia yang merupakan elemen penting dalam sebuah organsisai tidak mampu diorganisir secara baik

${ }^{11}$ George R, Terry alih bahasa J. Smith, D.F.M., Prinsip Prinsip Manajemen (Jakarta;Bumi Aksara, 1991) Hal. 76 
maka akan muncul sebuah kebatilan dalam sebuah organisasi. Sayyidina Ali bin Abi Thalib pernah berkata $:^{12}$

\section{الحق بلا نظام بغلبه البا طل بنظام}

Artinya : Kebenaran yang tidak terorganisasi dengan rapi, dapat dikalabkan oleh kebatilan yang diorganisasi dengan baik.

Maka dari itu banyak sebuah kehancuran dari sebuah institusi atau organisasi adalah karena sebuah orgnasisasi yang tidak menjalankan manajemen secara maksimal

\subsection{Actuating (penggerakan)}

Menurut Onong Uchjana Effendi, actuating adalah penggerakan atau penggiatan yang berarti upaya pengerahan sambil merangsang para anggota kelompok agar melaksanakan tugas-tugasnya dengan gairah atau semangat. ${ }^{13}$ Pengerahan ini meliputi kegiatan-kegiatan memimpin, membimbing dan mengarahkan, kegiatan-kegiatan sedemikian rupa sehingga anggota kelompok itu memiliki aktifitas serta kreatifitas dalam melaksanakan rencana dan menggapai tujuan yang telah ditetapkan. Upaya pengerahan tersebut dapat berupa pengeluaran perintah, instruksi, maupun memberi konseling (bimbingan), pada bawahannya agar merasa tergerak hatinya untuk melaksanakan tugas-tugas dengan baik.

Allah berfirman dalam surat Al-Baqarah ayat 208:

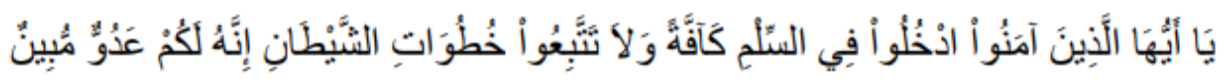

Artinya: Hai orang-orang yang beriman, masuklah kamu kedalam Islam keselurubannya dan janganlah kamu turuti langkah-langkah setan, karena setan itu musubmu yang nyata. (Q.S Al-Baqarah ayat 208)

Dari ayat diatas agama pun juga telah mengajarkan tentang upaya pengerahan bahwa untuk mencapai hasil yang baik, sesuai tujuan dan sesuai dalam sebuah perencanaan (planning) maka berlandaskanlah pada sebuah kebaikan dalam Islam dimana dalam Islam itu mengajarkan sebuah kedamaian, kerjasama, dan hal-hal baik lainnya.

\subsection{Controlling (pengawasan)}

Menurut Robert J. Mocker dalam bukunya, "The Management Control Process" definisi pengawasan adalah: ${ }^{14}$

"Suatu usaha sistematik untuk menetapkan standar pelaksanaan dengan tujuan-tujuan perencanaan, merangsang sistem informasi umpan balik, membandingkan kegiatan nyata dengan standar yang telah ditetapkan sebelumnya, menetapkan dan mengukur penyimpangan-penyimpangan, serta mengambil tindakan koreksi yang diperlukan untuk menjamin bahwa semua sumber daya perusahaan dipergunakan dengan cara paling efektif dan efisien dalam pencapaian tujuan tujuan perusahaan"

\footnotetext{
${ }^{12}$ Zainarti, Manajemen Islami Perspektif Al-Qur'an, Jurnal Iqra' Volume 08 No.01, 2014, Hal 5

${ }^{13}$ Onong Uchjana Effendi, Human Relation dan Public Relation dalam Manajemen. (Bandung : Alumni, 1986) Hal.8 
Jadi pengawasan merupakan tindakan atau proses kegiatan untuk mengetahui hasil pelaksanaan, kesalahan, kegagalan, untuk kemudian dilakukan perbaikan dan mencegah terulangnya kembali kesalahankesalahan itu, begitu pula menjaga agar pelaksanaan tidak berbeda dengan rencana yang ditetapkan. Fungsi-fungsi pengawasan antara lain $:^{15}$

1. Menjaga terjadinya berbagai penyimpangan atau kesalahan kesalahan

2. Untuk memperbaiki berbagai penyimpangan atau kesalahan yang terjadi

3. Untuk mendinamisir organisasi serta segenap kegiatan manajemen lainnya

4. Untuk mempertebal rasa tanggung jawab setiap bagian berikut karyawannya terhadap semua tugas yang dilakukan

Dalam agama islam, controlling atau pengawasan juga merupakan syarat mutlak bagi seorang pemimpin untuk terus lebih baik dari anggotanya hal ini dikarenakan agar tercipta sebuah kontrol yang efektif.

Dalam Q.S Ash-Shaff Allah berfirman :

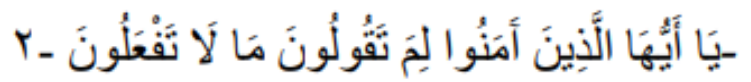

Artinya : Wahai orang-orang yang berman, kenapakah kamu mengatakan sesuatu yang tidak, kamu kerjakan? (Q.S Ash- Shaff ayat 2)

Dalam Q.S At-Tahrim Allah juga berfirman :

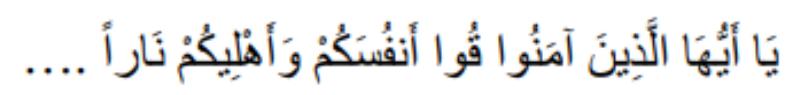

Artinya : Hai orang-orang yang beriman, peliharalah dirimu dan keluargamu dari api neraka... (Q.S At-Tahrim ayat 6)

Dua ayat diatas menyebutkan kata "beriman" dimana arti kata ini merujuk sebuah keimanan seseorang. Orang-orang yang beriman merupakan orang-orang yang percaya dan pasrah atas kehendak Allah dan meletakkan dirinya pada Din Islam.

Fungsi controlling merupakan tugas penting bagi seorang pemimpin, dan dari ayat diatas dapat diketahui bahwa agama pun mengajarkan bahwasannya barang siapa yang meletakkan hidupnya pada jalan yang benar maka semua akan berjalan dengan kebenaran. Dan ketika seorang pemimpin mampu memimpin anggotanya dengan asas dan dasar Din Islam maka sebuah organisasi atau instansi akan selalu amanah dan penuh kedamaian.

${ }^{15}$ Ibid, Hal. 102-103. 


\section{Media Islam dan Islami}

Secara eksplisit, sangat sulit mencari apa yang dimaksud dengan media islam. Namun ada beberapa gagasan dari Satrio Arisunandar, seorang dosen ilmu komunikasi Universitas Indonesia dan sekaligus mantan produser eksekutif divisi News di salah satu televisi swasta.

Menurut Arismunandar, frasa "media Islam" kata Islam itu mengarah pada identitas untuk membedakan satu dengan yang lain. Sehingga kalau kata "Islam" menunjukkan identitas, maka kata "Islami" menunjukkan suatu sifat atau ciri yang merujuk ke identitas "Islam." Sebagai konsekuensinya, untuk memiliki identitas Islam itu media harus memenuhi beberapa syarat yang diajukan, ada 3 syarat yang harus dipenuhi agar media bisa dikategorikan sebagai media Islam, diantaranya $:^{16}$

1. Syarat pertama, untuk bisa disebut sebagai "media islam', media itu harus dimiliki oleh orang Islam, atau jika kepemilikannya bersifat kolektif (misalnya, saham perusahaan media yang telah diperjualbelikan untuk umum di bursa efek) maka mayoritas saham harus dimiliki oleh orang Islam.

2. Syarat kedua, media itu sedikit banyak harus mengemban misi dakwah, yakni misi mengagungkan agama Allah, menyebarkan nilai-nilai ajaran Islam, memajukan dan mencerdaskan umat Islam, dan sebagainya. Misi dakwah disini bukan berarti bahwa seluruh konten harus mengenai dakwah islam, tetapi perwujudan misi dakwah bisa sangat luas.

Di sini, sudah masuk unsur kreativitas pengelola media dalam mengemas misi dakwahnya. Jadi, media Islam bebas menyajikan dan mengupas topik apa saja. Mulai dari topik yang spesifik berkaitan dengan agama, sampai topik yang terkait dengan ilmu pengetahuan, teknologi, sastra, seni-budaya, sosial-ekonomi, politik, dan lain-lain. Semua itu bisa dijadikan topik, asalkan semua itu dilandasi dengan niat dakwah. Jadi, misi media Islam bukan semata-mata komersial, bukan cuma mengejar profit sebanyak-banyaknya.

3. Syarat ketiga, media Islam harus menerapkan aturan, etika, dan nilainilai ajaran Islam, dalam menjalankan bisnis perusahaan media dan aktivitas keredaksian (editorial). Islam tidak mengenal prinsip tujuan menghalalkan cara. Jika syarat kedua tadi berkaitan dengan niat (misi) dan tujuan ketika mendirikan media, maka syarat ketiga ini berkaitan dengan cara mencapai tujuan tersebut.

Dalam aspek bisnis, misalnya, media Islam tidak membabi buta dalam mencarikeuntungan. Contohnya, tidak semua iklan, betapapun besar nilainya, akan diterima. Harus ada kriteria, iklan mana yang boleh atau tidak-boleh dimuat di media Islam. Media Islam akan menolak mengiklankan semua hal yang secara jelas dan tegasdiharamkan oleh Islam. Jadi, tidak akan ada iklan minuman keras atau makanan yang mengandungdaging babi di media Islam. Soal iklan rokok, ada yang tegas mengharamkan, ada jugayang menganggapnya makruh. Namun,

${ }^{16}$ Satrio Arismunandar, Media Islam, Media Islami, dan Perbedaannya dengan Media Lain (www.academia.edu) 
apapun yang dipilih, iklan rokok juga bukan sesuatu yang dianjurkan karena dampak negatifnya pada kesehatan.

Selain ketiga syarat diatas media Islam juga harus menerapkan peraturan ketenagakerjaan yang adil dan manusiawi untuk para buruhnya. Jangan sampai tenaga buruh diperas seenaknya dan diupah di bawah standar upah minimum yang layak. Sistem kerjanya juga harus memberi kesempatan karyawan untuk melaksanakan ibadah sholat, dan lain-lain. Dan juga bagi media Islam, pengertian kebebasan pers dan kebebasan berekspresi bukanlah kebebasan yang liar semau-maunya, bukan kebebasan demi kebebasan itu sendiri. Melainkan, kebebasan yang luas dalam berkreasi melalui media sebagai sarana dakwah dan wujud pengabdian kepada Allah SWT.

Melalui ketiga syarat diatas yang diajukan oleh Arismunandar masih masuk akal dan ideal secara konsep. Namun pada prakteknya masih sangat sulit ditemukan dilapangan. Mengingat nilai Islam harus melekat dari luar hingga akar dari sebuah instansi media, bila pemimpin media kurang kuat dan cerdas dalam menghadapi tuntuntan baik dari luar dan dalam, penulis yakin media yang bersangkutan tidak akan bertahan lama.

\section{Radio Suara Muslim Surabaya Manajemen Islam atau Islami}

Zainul Maarif menuliskan hasil penelitian dari Hossein Askari dan Scheherazade S. Rehman.

Beliau mengatakan bahwa yang "Islami" tidak selalu "Islam", sementara yang "Islam" belum tentu "Islami"17. Dan dua peneliti tersebut menulis artikelnya di Global Economy Journal yang berjudul "How Islamic are Islamic Countries?".

Mereka mengacu pada Al-Quran dan Sunnah Nabi untuk mengetahui karakterisitik negara "Islami", lalu menjadikan parameter tersebut sebagai alat teropong bagi ratusan negara. Dan hasilnya dapat disimpulkan bahwa negara Islam tidak selalu Islami, demikian pula negara yang mayoritasnya muslim belum tentu Islami, sedangkan negara non-Islam dan/atau mayoritasnya non-muslim justru mungkin bisa lebih Islami. Kesimpulan tersebut bisa diabstraksikan menjadi perbedaan antara makna Islam dan Islami. Misalnya dikatakan Negara Islam karena mayoritasnya masyarakatnya Islam namun belum tentu islami karena kebijakan dan peraturannya belum sesuai syariah Islam, tidak adil, semena-mena. Namun bisa juga dikatakan Islami karena bertindak adil kepada seluruh warga negaranya tanpa diskriminasi, masyarakat/individu berakhlak mulia, tidak ada yang korup. Sehingga makna Islami ini tidak berlandaskan pada label "Islam" namun pada keadilan dan kesetaraan dalam memberlakukan kebijakan dan memperlakukan kenggotaan sesuai dengan yang diajarkan Rasulullah SWT ketika memimpin umatnya.

Mengenai hal islam ataukah islami memang dirasa masih kurang banyak buku yang membahas kedua hal ini, namun jika melihat dari

${ }^{17}$ Zainul Maarif, Islam dan Islami dalam Syiar Nusantara, Kompasiana.com, 12 Januari 2018 
pendapat Aris Munandar mengenai syarat media Islam, Radio Suara Muslim Suara Surabaya memenuhi hal tersebut, diantaranya:

1. Dimiliki oleh orang Islam, Radio Suara Muslim Surabaya telah memenuhi syarat pertama ini karena radio ini dimiliki dan dipimpin oleh orang Islam selain itu harapan didirikannya Radio Suara Muslim ini adalah untuk mendidik sekaligus menyebarkan nilai-nilai kebaikan, membentuk masyarakat yang bermoral, berakhlak, dan berbudaya luhur. Selain itu juga bertujuan menanamkan moral yang baik serta mencerdaskan bangsa agar makin produktif dengan cara yang sesuai aturan serta norma sosial yang berlaku dengan diimbangi nilai-nilai keislaman.

2. Medianya sedikit banyak harus mengemban misi dakwah, menyebarkan nilai-nilai ajaran Islam dan mengagungkan nama Allah dan bila dilihat dari syarat ini isi dari program-program Radio Suara Muslim Surabaya sudah memenuhi syarat kedua ini. Radio Suara Muslim Surabaya memiliki prinsip "dengan satu mic sekali berujar, seribu telinga mendengar" prinsip ini dibuat dengan maksud berdakwah melalui radio lebih efektif dari pada berdakwah di masjid atau mimbar, sebab berdakwah dengan menggunakan media radio lebih besar jangkauannya dan lebih banyak yang mendengarkan daripada bertaklim di masjid yang hanya beberapa orang saja yang mendengarkanya dan sedikit jangkauannya.

Program - program yang disiarkan Radio Suara Muslim Surabaya juga bersifat umum namun tetap diimbangi dan dikaitkan dengan koridor-koridor Islam. Adapun program-program tersebut diantaranya Belajar Al-Quran, Bincang Editorial, Bincang Advertorial, Bincang Lifestyle, Tabloid Udara, Konsultasi Fiqih, Belajar Islam, Bincang Keluarga

Jika program-program tersebut bernilai umum maka akan diimbangi dengan atau tidak keluar dari batas syariat islam contohnya program Lifestyle yang membahas tentang pola hidup sehat yang membahas mengenai kesehatan. Apabila membahas kesehatan secara umum maka akan didatangkan narasumber dari dokter-dokter dan akan dikaitkan pula dengan kesehatan ala nabi dengan menyertakan hadist dan ayatayat Al-Qur'an didalam materi program tersebut.

3. Media Islam harus menerapkan aturan, etika, dan nilai-nilai ajaran Islam, dalam menjalankan bisnis perusahaan media dan aktivitas keredaksian (editorial). Disyarat yang ketiga ini ada beberapa kebijakan yang diterapkan oleh Radio Suara Muslim Surabaya yakni memberlakukan kebijakan standart minimal 7 (tujuh) amalan harian yang harus dilakukan oleh setiap karyawan sebelum melakukan kegiatan kantor atau pekerjaan 


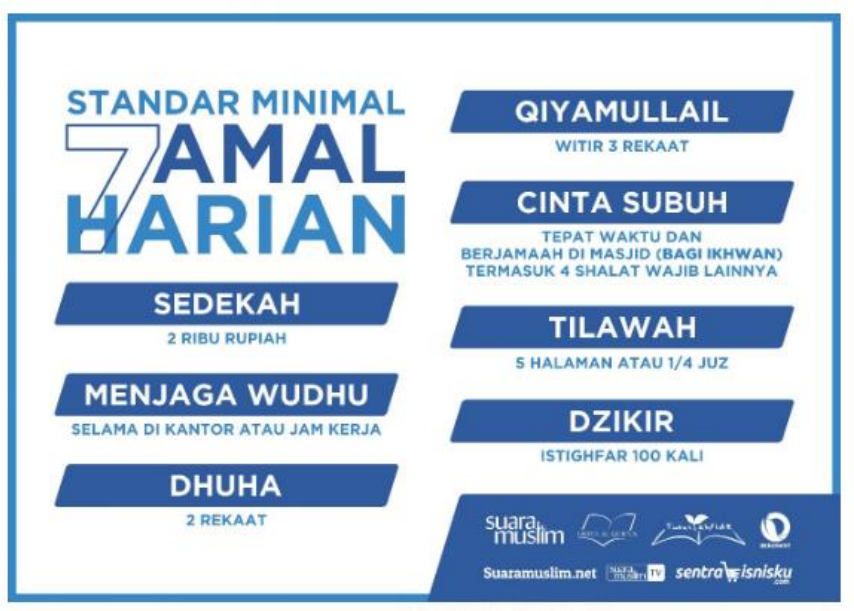

Standar minimal 7 amal harian tersebut merupakan ibadah yang harus dilaporkan dan dilakukan setiap harinya sebelum melakukan pekerjaan. Pelaporan tersebut dilakukan via link google form dan sebagai bentuk penilaian individual walaupun kebenaran pelaporan mengenai sudah atau belumnya 7 amalan tersebut dilakukan oleh para pekerja Radio Suara Muslim Surabaya namun besar harapan pimpinan Radio Suara Muslim Surabaya dengan adanya standar minimal 7 amal harian tersebut agar para pekerja menjadi pribadi yang lebih baik.

Salah satu fungsi manajemen yakni organizing (pengorganisasian), dimana pemimpin merorganisir para anggotanya disini pimpinan Radio Suara Muslim Surabaya mengorganisir para pekerjanya dengan harapan para pekerjanya menjadi pribadi yang lebih baik sesuai syariat Islam dimana Allah berfirman dalam surah Al-Imran :

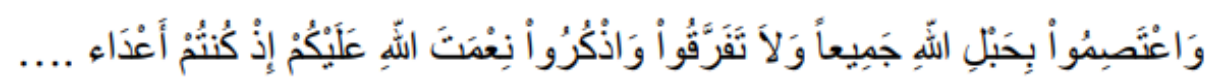

Artinya: Dan berpeganglah kamu semuanya pada tali (agama) Allah, dan janganlah kamu bercerai-berai, dan ingatlah akan nikmat Allah kepadamu ketika kamu dabulu (masa jabiliyah) bermusub-musuban... (Q.S Al-Imran ayat 103)

Dari ayat diatas ketika sekumpulan orang berpegang pada tali (agama) Allah dan mampu diorganisir dengan baik maka akan terjalin sebuah kerjasama yang baik dan efektif.

Jika kita membedah dari standart minimal 7 amalan harian Radio Suara Muslim Surabaya adalah pentingnya mendirikan shalat dimana dalam Q.S Al Ankabut Allah berfirman:

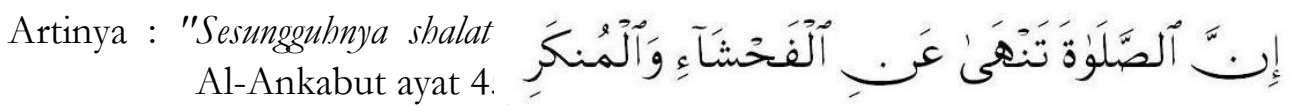

Dilihat dari ayat diatas dimana adanya amalan shalat dalam standart amalan harian Radio Suara Muslim Surabaya ini diharapkan menjadi sarana untuk memperbaiki perilaku, sehingga para karyawan menjadi 
pribadi yang lebih baik, husnudzon dalam berpikir, sabar dalam menghadapi pekerjan, tidak mudah mengeluh dalam bekerja, dan banyak perilaku baik lainnya.

Ada pula amalan harian lain yakni sedekah, Allah telah banyak berfirman mengenai sedekah salah satunya di Q.S Al-Baqarah, 265 :

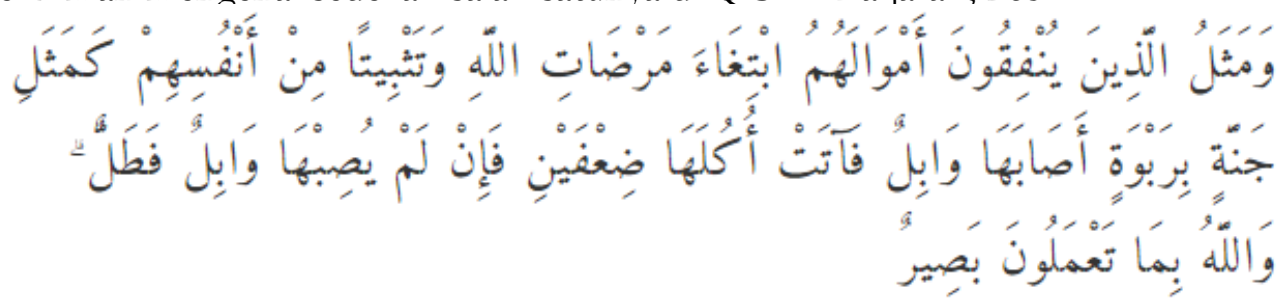

Artinya : Dan perumpamaan orang-orang yang membelanjakan hartanya karena mencari keridhaan Allah dan untuk. keteguban jiwa mereka, seperti sebuah kebun yang terletak di dataran tinggi yang disiram oleh hujan lebat, maka kebun itu menghasilkan buahnya dua kali lipat. Jika hujan lebat tidak menyiraminya, maka bujan gerimis (pun memadai). Dan Allah Maha Melihat apa yang kamu perbuat. (QS. Al-Baqarah, 265)

Selain itu hadist riwayat Thabrani dalam Mu'jamul Kabir dimana beliau mengatakan :

"Sedekah dapat menolak 70 macam bencana, dan yg paling ringan (di antara bencana itu) adalah penyakit kusta dan lepra,"

Sumber hadist dan Al-Qur'an diatas jelas mengatakan bahwa sedekah merupakan amalan yang dapat menjauhkan dari bala dan bencana, sehingga dengan adanya standart amalan harian Radio Suara Muslim Surabaya yang diberlakukan kepada pekerja adalah dengan melakukan amalan tersebut para pekerja dijauhkan dari bala dan bencana, membuka pintu rezeki, dan ikhlas bekerja untuk mencari keridhaan Allah.

Sehingga dari 7 standart minimal amalan harian yang diberlakukan oleh Radio Suara Muslim Surabaya dimana amalan-amalan tersebut merupakan kegiatan ritual-ritual dalam islam yang dimaksudkan untuk menyempurnakan perilaku baik, dimana seseorang yang sudah baik bisa menjadi lebih baik lagi, dan ketika para karyawan bekerja dengan keikhlasan hati, menjemput keridhaan Allah, husnudzon, berkepala dingin, dan berperilaku baik maka akan menghasilkan kefektifan kerja yang baik pula yang dapat membangun perusahaan menjadi lebih baik karena SDM (Sumber Daya Manusia) yang menjadi elemen penting dalam sebuah organisasi mampu diorganisir dengan baik. 


\section{Kesimpulan}

Secara eksplisit, sangat sulit mencari apa yang dimaksud dengan media islam. Namun gagasan dari Satrio Arisunandar yang mengatakan bahwa frasa "media Islam" kata Islam itu mengarah pada identitas untuk membedakan satu dengan yang lain. Sehingga kalau kata "Islam" menunjukkan identitas, maka kata "Islami" menunjukkan suatu sifat atau ciri yang merujuk ke identitas "Islam."

Tiga syarat media Islam yang dikatakan Satrio Arismunandar menjadi pedoman untuk menilai manajemen dalam Radio Suara Muslim Surabaya bernilai Islam atau Islami, yang diantara syarat tersebut adalah :

1. Media harus dimiliki oleh orang Islam, dan Radio Suara Muslim Surabaya dimiliki dan dipimpin oleh orang Islam

2. Media Islam sedikit banyaknya harus mengemban misi dakwah, dan Radio Suara Muslim Surabaya memiliki program-program untuk menyebarkan agama islam dengan prinsip "dengan satu mic sekali berujar, seribu telinga mendengar” prinsip ini dibuat dengan maksud berdakwah melalui radio itu lebih efektif

3. Media Islam harus menerapkan aturan, etika, dan nilai-nilai ajaran Islam, dan Radio Suara Muslim Surabaya memberlakukan aturan standart minimal 7 amalan harian yang dimana harapan dari amalan tersebut dapat diimplementasikan dengan baik dan pekerja menjadi pribadi yang lebih baik, sehingga ketika para pekerja mampu diorganisir dengan baik maka perusahaan akan berjalan dengan baik dan efektif

Sehingga dari kebijakan yang dibuat oleh Radio Suara Muslim Surabaya maka manajemen Radio Suara Muslim Surabaya hampir mendekati dengan Islam yang Islami.

\section{A. Daftar Pustaka}

Abu Sinn Ahmad Ibrahim. Manajemen Syariah Sebuah Kajian Histories Dan Kontemporer. Jakarta : PT Raja Grafindo Persada, 2008.

Al-Buraey, A.Muhammad. Islam LandasanAlternatif Administratif Pembangunan. Jakarta : CV Rajawali, 1986.

Arismunandar, Satrio. Media Islam, Media Islami, dan Perbedaannya dengan Media Lain. 2018.

Effendi, Onong Uchjana. Human Relation dan Public Relation dalam Manajemen. Bandung : Alumni, 1986.

Julitriarsa, Djati dan John Suprihanto. Manajemen Umum Sebuah Pengantar. Yogyakarta: BPFE, 1998.

Maarif, Zainul. Islam dan Islami dalam Syiar Nusantara. dalam Kompasiana.com, 2018. Muhammad. Manajemen Dana Bank Syariah. Yogyakarta: Ekonisia, 2005.

Romli, Asep Syamsul dan M. Dasar-Dasar Siaran Radio. Bandung: Nuansa, 2009.

Silalahi, Ulber. Metode Penelitian Sosial. Bandung: PT Refika Aditama, 2012.

Sudibyo, Agus. Ekonomi Politik Media Penyiaran. Yogyakarta:LkiS, 2004.

Sugiyono. Metode Penelitian Kualitatif, Kuantitatif dan R\&D. Bandung: PT. Alfabet, 2016.

Terry, George R. Prinsip Prinsip Manajemen. Jakarta: Bumi Aksara, 1991.

Widjaja, HA. Imu Komunikasi. Jakarta: Rineka Cipta, 2000.

Winardi. Asas-asas Manajemen. Bandung: Alumni, 1986. 
Yanuar Nugroho, Shita Laksmi. Jurnal Lanskap Industri Media di Indonesia

Zainarti. Jurnal Iqra' Volume 08 No.01: Manajemen Islami Perspektif Al-Qur'an, 2014. 